\title{
Peer Assessment of Soft Skills and Hard Skills
}

\author{
Aimao Zhang \\ Georgia Southern University, Statesboro, GA, USA \\ aimao@georgiasouthern.edu \\ Executive Summary
}

Both the information technology (IT) industry and the Accreditation Board for Engineering and Technology (ABET) demand soft-skill training in higher education and require IT graduates to demonstrate competence in interpersonal communication, teamwork, and conflict management. Group projects provide teamwork environment for soft-skill training, but their practical success is difficult to assess. Group activities often take place outside classroom, and instructors are kept out of communication and interaction loops. Free-rider problems arise when some students are doing less work and awarded the same grades as others who contribute more. Many studies have suggested that, for group projects, peer evaluation is more effective than instructor evaluation. However, most peer assessment scales are ad hoc, neither standardized nor well-structured.

This study designed a peer assessment scale for soft-skill and hard-skill evaluations. The assessment scale was administrated in an IT course and data was collected. Two dimensions, soft-skill and hard-skill, emerged from factor analysis and captured 67 percent of variance. Items on the assessment scale passed a reliability test with Cronbach's $\alpha$ values greater than 0.70 .

IT education should prepare future IT professionals with hard and soft skills to communicate with end users, to resolve conflicts, and to bring different functions together toward a common goal. This study should prove valuable for educators to promote soft-skill training in an active learning environment and to use peer evaluations to achieve success in IT education.

Keywords: peer evaluation, factor analysis, soft skills, group project

\section{Introduction}

Group projects have become increasingly important due to two driving forces. First, the Information Technology (IT) industry and Accreditation Board for Engineering and Technology (ABET) require college graduates to attain skills in interpersonal communication, teamwork, and conflict management (Aasheim, Li, \& Williams, 2009). Second, colleges and universities are shifting their pedagogical approaches from passive to active learning, from class lecture ("sage on the stage") to cooperative learning ("guide on the side"; Tagg, 2003). However, for group projects to be successful, a validated peer assessment tool is essential. This study aimed to promote soft-skill

Material published as part of this publication, either on-line or in print, is copyrighted by the Informing Science Institute. Permission to make digital or paper copy of part or all of these works for personal or classroom use is granted without fee provided that the copies are not made or distributed for profit or commercial advantage AND that copies 1) bear this notice in full and 2) give the full citation on the first page. It is permissible to abstract these works so long as credit is given. To copy in all other cases or to republish or to post on a server or to redistribute to lists requires specific permission and payment of a fee. Contact Publisher@InformingScience.org to request redistribution permission. training by designing and validating a peer assessment scale. In this paper, I will describe challenges and demands faced by educators, review literature, report the design of the scale and the factor analysis. 


\section{Literature Review: Challenges and Demands}

\section{Demand for Soft Skills}

In a recent survey, 348 IT managers were asked to rate the importance of various skills (Aasheim et al., 2009). Soft skills were rated high (see Table 1), while hard skills related to knowledge of operating systems, hardware, databases, security, web development languages, telecommunications, and networking were rated much lower.

Table1: Top 17 Skills Ranked by 348 IT Managers

\begin{tabular}{lll}
\hline \multicolumn{1}{c}{ Skills and Traits } & Scale of 1 to 5 \\
\hline 1. Honesty/integrity & 4.62 \\
\hline 2. Communication skills & 4.54 \\
\hline 3. $\quad$ Analytical skills & 4.51 \\
\hline 4. $\quad$ Ability to work in teams & 4.49 \\
\hline 5. Interpersonal skills & 4.37 \\
\hline 6. Motivation & 4.37 \\
\hline 7. Flexibility/adaptability & 4.33 \\
\hline 8. Creative thinking & 4.18 \\
\hline 9. Organizational skills & 4.13 \\
\hline 10. Relevant work experience & 4.06 \\
\hline 11. Awareness of IT technology trends & 4.04 \\
\hline 12. Operating systems & 3.99 \\
\hline 13. Hardware concepts & 3.92 \\
\hline 14. Database & 3.92 \\
\hline 15. Security & 3.91 \\
\hline 16. Telecommunications/Networking & 3.90 \\
\hline 17. Web development languages & 3.85 \\
\hline Note: Original table lists 32 skills and traits. Source: Aasheim et al., 2009, p. 353.
\end{tabular}

ABET specified two program outcomes in its Criteria for Accrediting Computing Programs, "ability to function effectively on teams to accomplish a common goal" and "ability to communicate effectively with a range of audiences" (2010, p. 3). The concept of soft skills is not new to higher education. Accrediting agencies have recommended them for over half a century (American Society for Engineering Education, 1950). However, soft-skill training is still particularly weak in science and engineering programs (Schulz, 2008), and this deficit hampers the career progression of today's IT graduates (Williams, 2011). Like engineering programs, IT curricula are loaded with hard-skill courses, and adding a soft-skills course is almost impossible. To meet the demand for soft-skill competence, this study provides a tool for implementing and assessing soft-skill training in a hard-skills course. 


\section{Demand for Active and Deep Learning}

Pedagogical approaches can be classified as passive or active. In passive learning, students merely receive; the instructor designs the learning program, determines assessment criteria, delivers lectures, and evaluates student performance (Falchikov, 1986). In active learning, students participate in, or take full responsibility for, learning.

Learning can also be categorized as surface or deep (Tagg, 2003). Surface learning focuses on information and emphasizes repetition and memorization techniques. According to Tagg (2003, p. 70), "Deep learning is learning that takes root in our apparatus of understanding, in the embedded meanings that define us and that we use to define the world." Students engaged in deep learning have higher levels of intellectual development and satisfaction with higher education (Laird, Shoup, \& Kuh, 2005).

To achieve deep learning, group projects are more effective than methods such as essay tests or multiple choice tests. When 301 employers were surveyed and asked how effective the method of supervised/evaluated internship/community-based project is, $69 \%$ of them answered "Very effective"; $14 \%$ of them answered "Fairly effective"; the total was $83 \%$. When asked about effectiveness of multiple-choice tests, only $7 \%$ of them answered "Very effective", $25 \%$ of them answered "Fairly effective" (Figure 1).

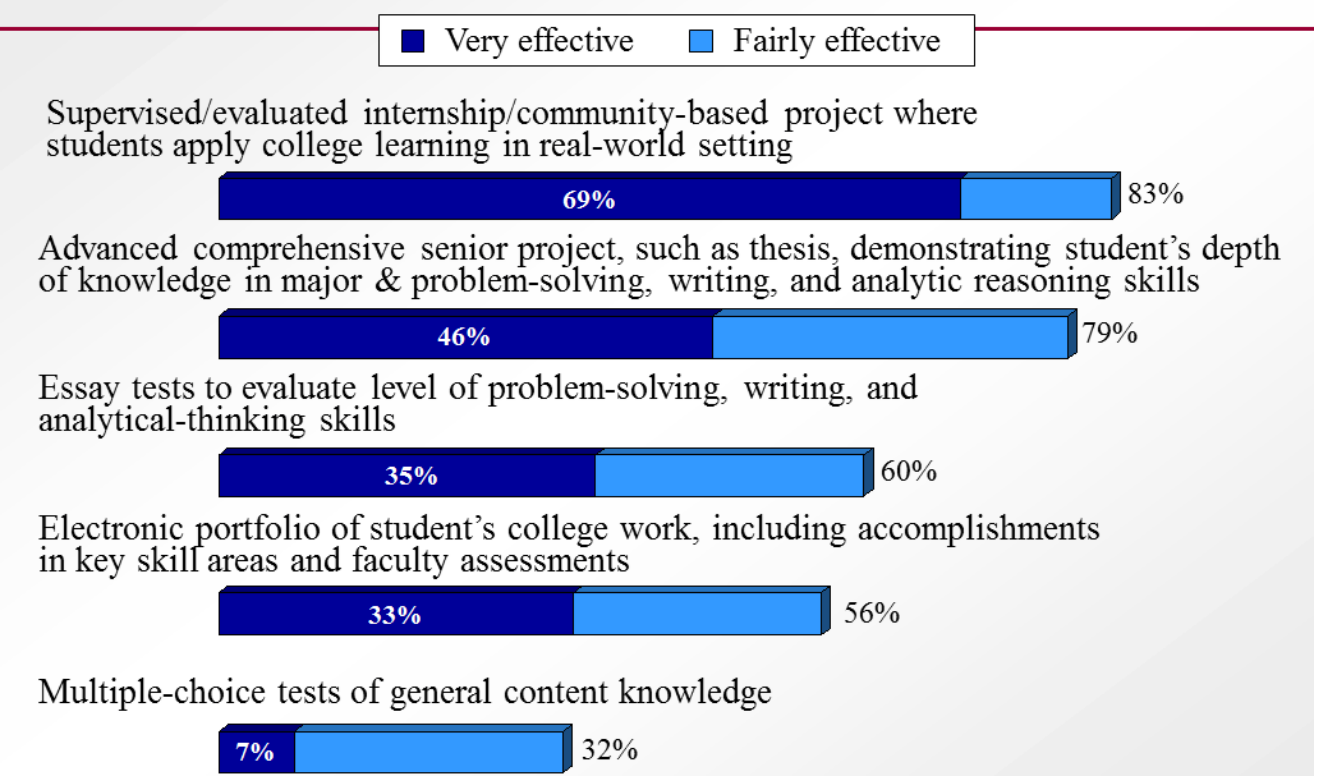

Figure 1: Effectiveness of Deep Learning

Source: Peter D. Hart Research Associates, Inc. (2008).

Numerous studies support the advantages of group projects, for instance, poster presentations on the use of the biosciences to solve industrial problems (Butcher \& Stefani, 1995), group presentations in pharmacology (Hughes \& Large,1993), case studies in production management (Kaimann, 1974), simulated training for groups in hotel management and tourism (Kwan \& Leung, 1996), team presentations in American history and literature (Oitzinger \& Kallgren, 2004), and team learning in business and organizational communication (Roebuck, 1998).

Compared with other fields, engineering programs are less likely to use deep learning methods (Laird et al., 2005). Laird, Shoup, and Kuh (2005) standardized the means of using deep learning methods in different programs and gave standardized mean of 0 to biology programs. The $\mathrm{Y}$-axis in Figure 2 represents standardized mean deviations. Both physical science and engineering programs were negatively deviated from 0 . It means that physical science and engineering programs 
used less deep learning methods than biology programs did. Social science, art, and education programs were positively deviated from 0 . It indicated a higher level of using deep learning methods in social science, art, and education programs.

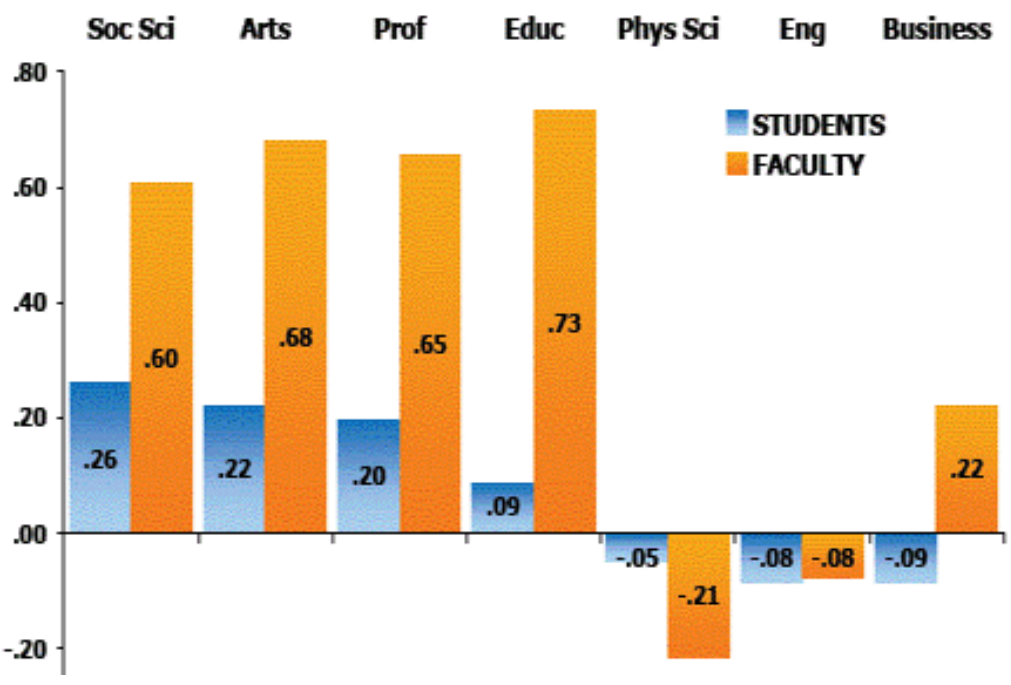

Figure 2: Disciplinary Comparisons of Standardized Means of Deep Learning Approaches Source: Kuh, Laird, \& Kinzie (2006).

\section{Challenges in Assessing Soft Skills}

In traditional pedagogy, quizzes, exams, and assignments are used to assess individual performance. Students have little input on the assessment criteria and process (Falchikov, 1986). Quizzes or exams cannot accurately measure interpersonal and leadership skills. While group projects provide excellent opportunities for soft-skill training, individual performance of group members is difficult to assess. Group activities often take place outside classroom, and instructors are kept out of communication and interaction loops. Free-rider problems arise when some students are doing less and awarded the same grades as others who contribute more.

Tremendous effort has been invested in specifying protocols and designing standardized assessment scales to measure the interpersonal communication skills of doctors, counselors, and nurses (Accreditation Council for Graduate Medical Education, 2005). The importance of this training for doctor and patient interaction during the diagnostic process or surgical team communication during an operation is easy to appreciate. Less effort has been invested in developing assessment scales to measure the soft skills of future IT professionals, who nonetheless must optimize teamwork and communicate effectively with a range of audiences. This study aims to improve IT education by designing and validating an assessment scale.

\section{Literature Review: Peer Evaluation}

\section{Definition and Importance of Assessment}

Assessment is defined as the activities and processes involved in judging performance. In peer assessment, students are involved in assessing the work of others (Reese-Durham, 2005).

Since Skinner's study of human behavior (1953), hundreds of studies have established that human behavior is shaped by intrinsic motivation and extrinsic rewards, and that extrinsic rewards positively influence intrinsic motivation (Deci, Koestner, \& Ryan, 1999). The performance assessment is an extrinsic reward that has tremendous influence over what and how students learn 
(Gibbs \& Haveshaw, 1989). It fosters learning habits and inevitably shapes the learning that takes place (Biggs, 1989).

\section{Positive Results of Peer Evaluation}

Many studies confirmed the validity and value of peer evaluation. Peer evaluation was shown to be more effective in predicting the success of first-year graduate study than GRE results, biographical and demographic surveys, and the Opinion, Attitude, and Interest Survey (Wiggins, Blackburn, \& Hackman, 1969). It is highly correlated with instructor evaluations and produces a typical grade distribution and a high degree of internal consistency (Burke, 1969; Hughes \& Large, 1993; Kaimann, 1974; Morton \& Macbeth, 1977; Pease, 1959). Orpen (1982) showed that there was no difference between peer and instructor evaluations in terms of absolute scores, average scores, variation of scores, and association of scores with final grades. J. S. Kane and Lawler (1978) concluded that peer evaluations provide a unique way to assess students' behaviors and that peers can accurately perceive and interpret each others' behavior and performance.

Peer evaluation also provides a learning opportunity for students to develop the ability to realistically judge the performance of others as well as their own. Boud \& Lublin (1983) considered peer assessment one of the most important teaching methodologies in undergraduate education. In a computer sciences course, 84 percent of students believed that evaluating their peers' work enhanced the educational process and reinforced what they had leaned (Rushton, Ramsey, \& Rada, 1993). Natriello (1987) reported that peer assessment had a profound effect on student learning. Fry (1990, p.181) validated five advantages of peer evaluation:

1. Students are encouraged to tackle problems outside the tutorial session.

2. In grading others' work, students appreciate and reinforce the correct solutions;

3. Students become aware of the grading scheme and appreciate the reasoning behind points awarded or deducted.

4. In grading others' work, students realize the importance of clearly presenting the solution.

5. The instructor can act as a facilitator rather than an assessor.

\section{Controversial Results of Peer Evaluation}

Not all findings are consistent with this positive view. Some studies reported that peer evaluations were significantly higher than those of either instructor or self (Friesen \& Dunning, 1973; Fuqua, Newman, Scott, \& Gade, 1986; Mowl \& Pain, 1995), while others found peer evaluations more stringent (Kwan \& Leung, 1996; Stefani, 1994). Rushton et al. (1993, p. 76) raised the following concerns:

1. Students may not have the same level of understanding of the subject matter as instructors;

2. Instructors are more likely to provide useful feedback;

3. Students may have to be told what points to look for when assessing others' work;

4. Students may be inclined to show bias toward their friends;

5. Students may be reluctant to award poor work low marks for fear of offending peers;

6. Students may not devote sufficient time and attention to this demanding task;

7. Students may be tempted to "borrow" ideas from other students for use in their own work. 


\section{Theoretical Foundation}

Regardless of whether or not peer assessment is superior to other assessment methods, the objective of this study is to move forward, to contribute to the body of research by designing and validating an assessment scale, and to promote soft-skill training by enabling students to evaluate their peers in group projects.

D. Johnson and Johnson's teamwork model (1997) proposes that group members perform two basic activities: task and social activities (Levi \& Cadiz, 1998). The theoretical framework of this study maps hard-skill training with task activities, such as attending meetings, preparing and delivering quality work, and providing ideas and initiatives. At the same time, it maps soft-skill training with social activities related to cooperation and communication, conflict resolution, trust building, and leadership.

Human behavior theory holds that human behavior is shaped by intrinsic motivation and extrinsic rewards. Merely providing soft- and hard-skills training is not sufficient to induce learning behavior. Providing accurate assessment as an extrinsic reward fosters and shapes the learning that takes place (Biggs, 1989; Gibbs \& Haveshaw, 1989; Skinner 1953). Figure 3 shows the theoretical framework of this study. Opportunities for training are independent variables; accurate assessments are moderator variables; and learning is the dependent variable. The model emphasizes both soft- and hard-skills training and the role of assessment in the learning process. The objective of this study is not to prove the proposed theory, but to develop an accurate assessment tool that would provide the needed extrinsic rewards.

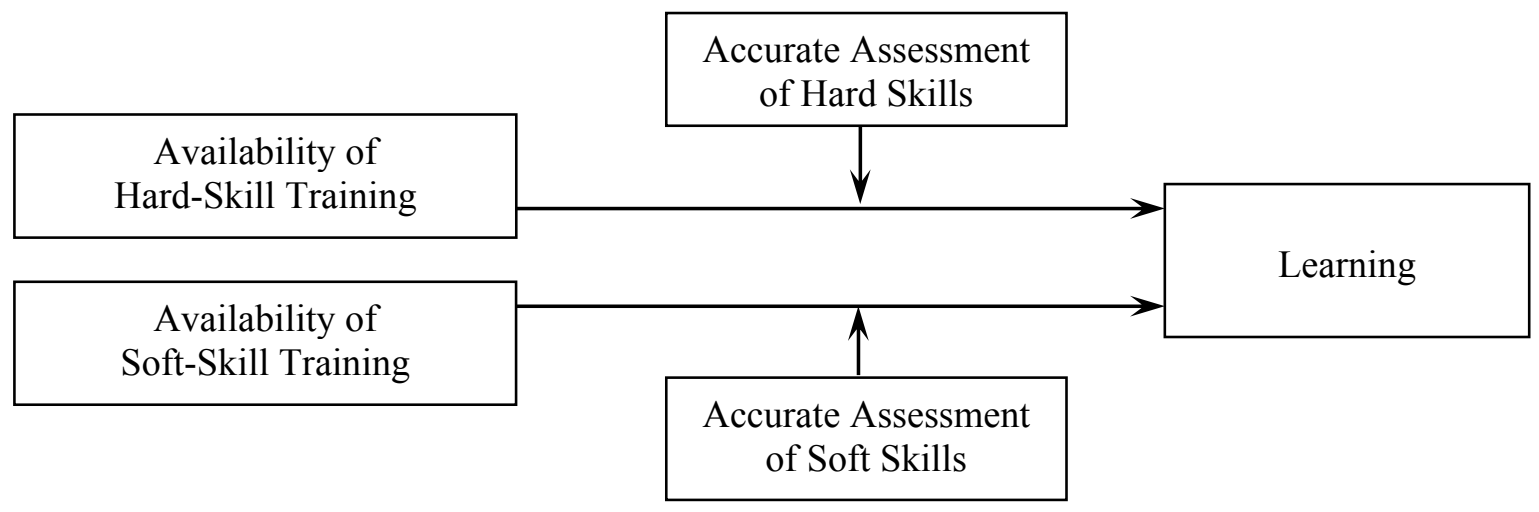

Figure 3. Theoretical Framework

\section{Design of the Assessment Scale}

To design the assessment scale, I reviewed the existing tools. Levi and Cadiz (1998) designed a peer assessment scale in which four items measure task activities and four items measure social activities. Gueldenzoph and May (2002) reviewed several peer evaluation studies and designed an 11-item scale for evaluating group presentations in a business communication course. Table 2 shows the design of the assessment scale for this study and source reference for each item. Items 1 through 8 are designed to measure hard skills; items 9 through 16, soft skills; item 17 is the overall grade, and item 18, the discriminate score. All items except 18 used a 5-point Likert scale. 
Table 2: Scale Items and Source References

\begin{tabular}{|c|c|}
\hline Item & Source References \\
\hline 1. Attends meetings & $\begin{array}{l}\text { Chalupa, Chen, \& Sormunen-Jones, 2000; } \\
\text { K. F. Johnson, 1993; Gueldenzoph \& May, } \\
2002\end{array}$ \\
\hline 2. Comes to meetings prepared & Odom, Glenn, \& Sanner, 2009 \\
\hline 3. Does quality work & $\begin{array}{l}\text { Chalupa, Chen, \& Sormunen-Jones, 2000; } \\
\text { Levi \& Cadiz, 1998; K. F. Johnson, } 1993\end{array}$ \\
\hline 4. Proposes quality ideas and initiatives & $\begin{array}{l}\text { Chalupa, Chen, \& Sormunen-Jones, 2000; } \\
\text { K. F.Johnson, } 1993\end{array}$ \\
\hline 5. Does more than fair share of work & $\begin{array}{l}\text { Chalupa, Chen, \& Sormunen-Jones, 2000; } \\
\text { Levi \& Cadiz, 1998; Odom, Glenn, \& } \\
\text { Sanner, } 2009\end{array}$ \\
\hline 6. Devotes time and effort to the project & K. F. Johnson, 1993 \\
\hline 7. Completes work on time & $\begin{array}{l}\text { Chalupa, Chen, \& Sormunen-Jones, 2000; } \\
\text { Levi \& Cadiz, 1998; K. F. Johnson, 1993; } \\
\text { Gueldenzoph \& May, } 2002\end{array}$ \\
\hline $\begin{array}{l}\text { 8. Understands concepts and has knowledge of } \\
\text { the project }\end{array}$ & Goldfinch, 1994 \\
\hline 9. Dependable and responsible & $\begin{array}{l}\text { Chalupa, Chen, \& Sormunen-Jones, 2000; } \\
\text { K. F. Johnson, } 1993\end{array}$ \\
\hline 10. Communicates with group members & $\begin{array}{l}\text { K. F. Johnson, 1993; Odom, Glenn, \& } \\
\text { Sanner, } 2009\end{array}$ \\
\hline $\begin{array}{l}\text { 11. Cooperates with and supports group } \\
\text { members (shares resource, ideas, } \\
\text { encouragement, constructive feedback) }\end{array}$ & $\begin{array}{l}\text { Chalupa, Chen, \& Sormunen-Jones, 2000; } \\
\text { Levi \& Cadiz, 1998; K. F. Johnson, 1993; } \\
\text { Gueldenzoph \& May, } 2002\end{array}$ \\
\hline $\begin{array}{l}\text { 12. Works through conflicts and handles } \\
\text { conflicts in a constructive manner }\end{array}$ & $\begin{array}{l}\text { Chalupa, Chen, \& Sormunen-Jones, 2000; } \\
\text { Levi \& Cadiz, 1998; Gueldenzoph \& May, } \\
2002\end{array}$ \\
\hline $\begin{array}{l}\text { 13. Respectful of others' ideas and stays positive } \\
\text { and open-minded }\end{array}$ & $\begin{array}{l}\text { Levi \& Cadiz, 1998; Odom, Glenn, \& } \\
\text { Sanner, } 2009\end{array}$ \\
\hline 14. Commits to group goal & $\begin{array}{l}\text { Chalupa, Chen, \& Sormunen-Jones, 2000; } \\
\text { Levi \& Cadiz, } 1998\end{array}$ \\
\hline 15. Takes a leadership role & $\begin{array}{l}\text { Odom, Glenn, \& Sanner, 2009; } \\
\text { Gueldenzoph \& May, } 2002\end{array}$ \\
\hline $\begin{array}{l}\text { 16. Organizes the group and helps it to function } \\
\text { as a team }\end{array}$ & Goldfinch, 1994 \\
\hline $\begin{array}{l}\text { 17. At this point, what grade would you give this } \\
\text { group member for the project? }\end{array}$ & K. F. Johnson, 1993 \\
\hline $\mathrm{A}$ & \\
\hline
\end{tabular}

18. Distribute a total of 100 points among your group members, including yourself. Member $1 \quad$ Member $2 \quad$ Member $3 \quad$ K. F. Johnson, 1993 Member 4_ Member 5 


\section{Assessment Administration and Data Collection}

\section{Course Background and Setting}

The senior-level IT course involved in this study met 3.5 hours per week for a 16 -week semester (see Table 3 for schedule). The class had 24 students, 5 women, 19 men, ranging in age from 20 to 31 , majoring in IT or pre-IT. Their total credit hours earned ranged from 43 to 168. Although students varied in terms of total credit hours earned, they had completed the prerequisites which include courses in HTML, CSS, JavaScript, Java, database management, and server configuration. The variation in total credit hours earned and other factors such as GPA, gender, age, race, and nationality were considered as constant in this study. Students were randomly assigned to 5 groups: PHP, Ajax, XML, HTML5, or RSS.

The first 3.5 weeks of the semester were a facilitating phase during which the instructor taught JSP, which has characteristics similar to those of PHP. This phase lowered the learning curve for PHP and other topics and established a teaching example for students to follow. During the next 2.5 weeks, each group learned one of the 5 topics: PHP, Ajax, XML, HTML5, or RSS. For each, the instructor provided a set of written program codes and a brief assignment instruction. Each group was responsible for figuring out the codes, learning and preparing to teach the topic to the rest of the class. After the 2.5 weeks of preparation, each group had 1.5 weeks to present a topic, run the labs, tutor students, and grade assignments and tests.

Table 3: Class Schedule

\begin{tabular}{|c|c|c|}
\hline Date & Topic & Activities \\
\hline $\begin{array}{l}3.5 \\
\text { week }\end{array}$ & JSP & Instructor teaches JSP with individual assignments \\
\hline $\begin{array}{l}2.5 \\
\text { week }\end{array}$ & $\begin{array}{l}\text { Group } \\
\text { learning }\end{array}$ & $\begin{array}{l}\text { - Textbook (Sebesta, 2010) } \\
\text { - Instructor provides each group with a set of program } \\
\text { codes and a brief assignment instruction } \\
\text { - Group prepares PPT presentation, assignment } \\
\text { instructions, test questions, and suggested reading } \\
\text { materials } \\
\text { - Collect first-round peer evaluations within all groups }\end{array}$ \\
\hline $\begin{array}{l}1.5 \\
\text { week }\end{array}$ & PHP & \multirow{5}{*}{$\begin{array}{l}\text { 5 Groups Teach } 5 \text { Topics } \\
\text { - Each group gives lectures and tours labs } \\
\text { - The class is given a project assignment, a written test, } \\
\text { and an online quiz for each topic } \\
\text { - The class evaluates each group. } \\
\text { - Collect the second round of peer evaluations. }\end{array}$} \\
\hline $\begin{array}{l}1.5 \\
\text { week }\end{array}$ & Ajax & \\
\hline $\begin{array}{l}1.5 \\
\text { week }\end{array}$ & XML & \\
\hline $\begin{array}{l}1.5 \\
\text { week }\end{array}$ & HTML5 & \\
\hline $\begin{array}{l}1.5 \\
\text { week }\end{array}$ & RSS & \\
\hline Final & & Term Paper on Group Teaching \\
\hline
\end{tabular}




\section{Data Collection}

The assessment scale was presented to the class at the beginning of the semester, so students would have a clear understanding of the evaluation criteria and who would evaluate them. This preparation motivated students to improve their skills when interacting with peers.

Within the groups, each member evaluated peers including him or herself twice during the semester. The first round was administered at the end of group learning; the second, at the end of group teaching (see Table 3 for the data collection schedule). The assessment scale was created using tools at surveymonkey.com. A hyperlink was provided on the Blackboard Learning System, where other course materials were posted. The data were automatically collected at surveymonkey.com.

\section{Result of a Factor Analysis}

The sample is based on 24 students and is small. To ensure sampling adequacy, the KaiserMeyer-Olkin (KMO) and Bartlett's tests were conducted. The recommended minimum value of KMO is 0.50 (Pett, Lackey, \& Sullivan, 2003). The assessment's KMO score of 0.948 was greater than 0.5 (see Table 4), indicating adequate sampling. Bartlett's test examined the null hypothesis of the correlation matrix being an identity matrix. With a degree of freedom of 136 and $p$ value of 0.000 , the null hypothesis was rejected.

Table 4: Kaiser-Meyer-Olkin (KMO) and Bartlett's Test

\begin{tabular}{llr} 
Kaiser-Meyer-Olkin Measure of Sampling Adequacy & 0.948 \\
\hline \multirow{3}{*}{ Bartlett's Test of Sphericity } & Approx. Chi-Square & 3623.616 \\
\cline { 2 - 3 } & df & 136 \\
\cline { 2 - 3 } & Sig. & 0.000 \\
\hline
\end{tabular}

Item 18 was a discriminate measurement, not designed for measuring soft or hard skills, so it was eliminated from the factor analysis. Factor analysis was performed on data using SPSS software. 2 factors emerged from analysis and captured 67 percent of variance (Table 5). All items have loading percentages on both factors. The loading percentages greater than 0.5 were printed in Table 6 and loading percentages less than 0.5 were left blank for clarity. The "Blank" option was set at 0.5 , so SPSS printed blanks for any correlations of 0.5 or less (Table 6).

Table 5: Total Variance Explained

\begin{tabular}{crrrrr}
\hline \multicolumn{2}{c}{ Extraction Sums of Squared Loadings } & \multicolumn{3}{c}{ Rotation Sums of Squared Loadings } \\
Total & $\%$ of Variance & Cumulative \% & Total & \% of Variance & Cumulative \% \\
10.553 & 62.075 & 62.075 & 5.810 & 34.175 & 34.175 \\
\hline 0.838 & 4.930 & 67.005 & 5.581 & 32.830 & 67.005 \\
\hline
\end{tabular}

Item 6 had loadings of 0.539 and 0.697 on factor 1 and factor 2 respective. Item 9 had loadings of 0.694 and 0.508 on factor 1 and factor 2 respective. These loadings were close, but discriminative enough to sign item 6 to factor 1 and item 9 to factor 2 .

The next question would be what constructs the factor 1 and factor 2 represent? Let go back to the design of the assessment scale and its items in Table 2, where items 1 through 8 were designed to measure hard skills; items 9 through 16 were to measure soft skills; and item 17 was the overall grade. Since items 1-8 were loaded on factor 1, we can interpret that factor 1 is the softskill factor. For the same reason that items 9-16 were loaded on factor 2, we can interpret that factor 2 is the hard-skill factor. In conclusion, the factor analysis indicated that the peer assess- 
ment scale has two separate dimensions (soft and hard skills), and possesses the capability to measure hard skill and soft skill. The analysis indicated the validity of the assessment tool which is the degree to which the instrument measures what it claims or is designed to measure.

\section{Table 6: Rotated Factor Matrix}

\begin{tabular}{lcc} 
& \multicolumn{2}{c}{ Factor } \\
& 1 & 2 \\
\hline Item 1 & & 0.575 \\
\hline Item 2 & & 0.777 \\
\hline Item 3 & & 0.867 \\
\hline Item 4 & & 0.698 \\
\hline Item 5 & & 0.759 \\
Item 6 & 0.539 & 0.697 \\
\hline Item 7 & & 0.607 \\
\hline Item 8 & & 0.506 \\
Item 9 & 0.694 & 0.508 \\
\hline Item 10 & 0.737 & \\
\hline Item 11 & 0.753 & \\
\hline Item 12 & 0.712 & \\
\hline Item 13 & 0.757 & \\
\hline Item 14 & 0.718 & \\
Item 15 & 0.656 & \\
\hline Item 16 & 0.679 & \\
\hline Item 17 & 0.514 & 0.621 \\
\hline & &
\end{tabular}

Reliability is the consistency of a measuring instrument. Reliability was analyzed by examining Cronbach's $\alpha$ values (1951). A Cronbach $\alpha$ value of 0.70 or higher is sufficient for social studies. All items passed reliability test with Cronbach's $\alpha$ values greater than 0.70 (see Table 7). High Cronbach's $\alpha$ values indicated a high degree of reliability of the scale.

Item 17 is an overall grade of A, B, C, D, or F, and should evaluate both hard skills and soft skills. If item 17 evaluates hard skills and soft skills equally, it should load 0.5 on soft skill factor and 0.5 on hard skill factor. The test result shows that item 17 slightly favored hard skills $(0.621$ over 0.514 ). In a hypothetical case when the instrument is administrated, group member A scored $100 \%$ on soft-skill and $0 \%$ on hard-skill, and group member B scored $100 \%$ on hard-skill and $0 \%$ on soft-skill, group member B will get a higher overall grade on item 17 than group member A. This bias could be due to the fact that students majoring in IT are hard-skill orientated or that our IT program emphasizes hard skills over soft skills. 
Table 7: Reliability Analysis

\begin{tabular}{lr}
\hline & Cronbach's $\alpha$ \\
Item 1 & 0.938 \\
\hline Item 2 & 0.930 \\
\hline Item 3 & 0.930 \\
\hline Item 4 & 0.930 \\
\hline Item 5 & 0.930 \\
\hline Item 6 & 0.928 \\
\hline Item 7 & 0.934 \\
Item 8 & 0.940 \\
Item 9 & 0.923 \\
\hline Item 10 & 0.924 \\
\hline Item 11 & 0.922 \\
\hline Item 12 & 0.926 \\
\hline Item 13 & 0.931 \\
\hline Item 14 & 0.928 \\
\hline Item 15 & 0.929 \\
Item 16 & 0.927 \\
\hline Item 17 & 0.935 \\
\hline
\end{tabular}

\section{Conclusion and Limitations}

Group projects provide teamwork environment for soft-skill training, but individual performance of group members is difficult to assess. This study designed an assessment scale for peer evaluations on soft and hard skills. A factor analysis validated the underlying dimensions - soft and hard skills.

IT education must prepare future IT professionals with hard and soft skills to communicate with end users, to resolve conflicts, and to bring different functions together toward a common goal. This study should prove valuable for educators to promote soft-skill training in an active learning environment and to use peer evaluations to achieve success in IT education.

This study used a small sample size of 24 students in a particular field of IT. The result has weak generalizability. This study is an initial step in designing and validating a peer assessment scale. In future studies, researchers may consider refinement and adjustment of the scale, using bigger sample size, and testing the assessment scale under different contexts or in different courses.

\section{References}

Aasheim, C., Li, L., \& Williams, S. (2009). Knowledge and skill requirements for entry-level information technology workers: A comparison of industry and academia. Journal of Information Systems Education, 20(3), 349-356.

ABET. (2010). Criteria for accrediting computing programs. Retrieved from http://www.abet.org/uploadedFiles/Accreditation/Accreditation_Process/Accreditation_Documents/Cu rrent/cac-criteria-2012-2013.pdf 
Accreditation Council for Graduate Medical Education. (2005). Advancing education in interpersonal and communication skills: An educational resource from the ACGME outcome project. Retrieved from http://www.acgme.org/outcome/implement/interpercomskills.pdf

American Society for Engineering Education. (1950). Speaking can be easy for engineers, too: A concise practical approach to better public speaking and to better meetings. Prepared through the joint efforts of men in industry, education and professional engineering, many of whom are members of the Relations with Industry Division, New York.

Biggs, J. B. (1989). Approaches to the enhancement of tertiary teaching. Higher Education Research and Development, 8(1), 7-25.

Boud, D. \& Lublin, J. (1983). Student self-assessment: Educational benefits within existing resources. In G. Squires (Ed.), Innovation through recession (Vol. 1, pp. 93-99). Guildford, Surrey, England: Society for Research into Higher Education.

Burke, R. J. (1969). Some preliminary data on the use of self-evaluations and peer ratings in assigning university course grades. The Journal of Educational Research, 62(10), 444-448.

Butcher, A., \& Stefani, L. (1995). Analysis of peer-, self- and staff-assessment in group project work. Assessment in Education: Principles, Policy \& Practice, 2(2), 165-185.

Chalupa, M. R., Chen, C. S., \& Sormunen-Jones, C. (2000). Reliability and validity of the group member rating form. Delta Pi Epsilon Journal, 42(4), 35-45.

Cronbach, L. J. (1951). Coefficient alpha and the internal structure of tests. Psychometrika, 16(3), 297-334.

Deci, E. L., Koestner, R., \& Ryan, R. M. (1999). A meta-analytic review of experiments examining the effects of extrinsic rewards on intrinsic motivation. Psychological Bulletin, 125(6), 627-68.

Falchikov, N. (1986). Product comparisons and process benefits of collaborative peer group and self assessments. Assessment and Evaluation in Higher Education, 11(2), 146-66.

Friesen, D. D. \& Dunning, G. B. (1973). Peer evaluation and practicum supervision. Counselor Education and Supervision, 12(3), 229-35.

Fry, S. (1990). Implementation and evaluation of peer marking in higher education. Assessment and Evaluation in Higher Education, 15(3), 177-89.

Fuqua, D. R., Newman, J. L., Scott, T. B., \& Gade, E. M. (1986). Variability across sources of performance ratings: further evidence. Journal of Counseling Psychology, 33(3), 353-356.

Gibbs, G., \& Habeshaw, T. (1989). Preparing to teach. Bristol: Technical and Educational Services, Ltd.

Gueldenzoph, L. E., \& May, G. L. (2002). Collaborative peer evaluation: Best practices for group member assessments. Business Communication Quarterly, 65(1), 9-20.

Goldfinch, J. (1994). Further developments in peer assessment of group projects. Assessment \& Evaluation in Higher Education, 19(1), 29-35.

Hughes, I. E., \& Large, B. J. (1993). Staff and peer-group assessment of oral communication skills. Studies in Higher Education, 18(3), 379-85.

Johnson, D., \& Johnson, R. (1997). Joining together : Group theory and group skills (6th ed.). Boston: Allyn and Bacon.

Johnson, K. F. (1993 August). Team peer evaluations: A student-generated quantitative measurement of group membership performance. Proceedings of the 76th Annual Meeting of the Association for Education in Journalism and Mass Communication, Kansas City, MO.

Kaimann, R. (1974). The coincidence of student evaluation by professor and peer group using rank correlation. Journal of Educational Research, 68(4), 152-153.

Kane, J. S., \& Lawler, E. E. (1978). Methods of peer assessment. Psychological Bulletin, 85(3), 555-586. 
Kane, L. (2004). Educators, learners and active learning methodologies. International Journal of Lifelong Education, 23(3), 275-286.

Kuh, G., Laird, T., \& Kinzie, J. (2006). Deep learning, liberal education, and institutional practice: Emerging findings, provocative lessons. Presentation at the annual meeting of the Association of American Colleges and Universities, Washington, DC. Retrieved from http://nsse.iub.edu/pdf/conference_presentations/2006/AACU2006DeepLearning_FINAL.pdf

Kwan, K., \& Leung, R. (1996). Tutor versus peer group assessment of student performance in a simulation training exercise. Assessment \& Evaluation in Higher Education, 21(3), 205-14.

Laird, T. N., Shoup, R. \& Kuh, G. (2005). Deep learning and college outcomes: Do fields of study differ? The Annual Meeting of the Association for Institutional Research, May 29 - June 1, 2005 San Diego, CA. Retrieved at http://airweb.org/images/deep_learning.pdf

Levi, D., \& Cadiz, D. (1998). Evaluating team work on student projects: The use of behaviourally anchored scales to evaluate student performance. ERIC Document Reproduction Service, ED424250.

Morton, J. B., \& Macbeth, W. (1977). Correlations between staff, peer, and self-assessments of fourth-year students in surgery. Medical Education, 11(3), 167-170.

Mowl, G., \& Pain, R. (1995). Using self and peer assessment to improve students' essay writing: A case study from geography. Innovations in Education and Training International, 32(4), 324-335.

Natriello, G. (1987). The impact of evaluation processes on students. Educational Psychologist, 22(2), 155175.

Odom, S., Glenn, B., \& Sanner, S. (2009). Group peer review as an active learning strategy in a research course. International Journal of Teaching and Learning in Higher Education, 21(1), 108-117.

Oitzinger, J., \& Kallgren, D. (2004). Integrating modern times through student team presentations. College Teaching, 52(2), 64-68.

Orpen, C. (1982). Student versus lecturer assessment of learning: a research note. Higher Education, 11(5), $567-572$.

Pease, D. (1975). Comparing faculty and school supervisor ratings for education students. College Student Journal, 9(1), 91-94.

Peter D. Hart Research Associates, Inc. (2008). How should colleges assess \& improve college learning? Retrieved from http://www.aacu.org/leap/documents/2008_Business_Leader_Poll.pdf

Pett, M. A., Lackey, N. R., \& Sullivan, J. J. (2003). Making sense of factor analysis: The use of factor analysis for instrument development in health care research. Thousand Oaks, CA: Sage.

Reese-Durham, N. (2005). Peer evaluation as an active learning technique. Journal of Instructional Psychology, 32(4), 338-343.

Roebuck, D. (1998). Using team learning in business and organizational communication classes. Business Communication Quarterly, 61(3), 35-49.

Rushton, C., Ramsey, P., \& Rada, R. (1993). Peer assessment in a collaborative hypermedia environment: A case study. Journal of Computer-Based Instruction, 20(3), 75-80.

Schulz, B. (2008). The importance of soft skills: Education beyond academic knowledge. Journal of Language \& Communication, 2(1), 146-154.

Sebesta, R. (2011). Programming the World Wide Web (6th ed.). New York: Addison-Wesley.

Skinner, B. F. (1953). Science and human behavior. New York: Macmillan.

Stefani, L., (1994). Peer, self and tutor assessment: Relative reliabilities. Studies in Higher Education, 19(1), 69-75.

Tagg, J. (2003). The learning paradigm college. Bolton, MA: Anker Publishing Company. 
Wiggins, N., Blackburn, M., \& Hackman, J. R. (1969). Prediction of first-year graduate success in psychology: Peer ratings. The Journal of Educational Research, 63(2), 81-85.

Williams, J. (2011). Lack of soft skill training is curbing IT career progression. Computer Weekly. Retrieved from http://www.computerweekly.com/Articles/2011/08/26/247728/Lack-of-soft-skillstraining-is-curbing-IT-career-progression.htm

\section{Biography}

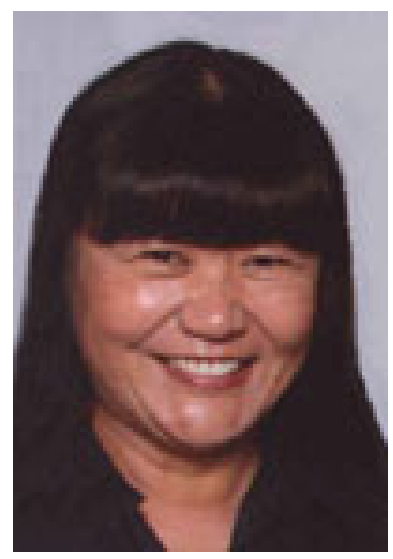

Aimao Zhang is an associate professor of Information Technology at Georgia Southern University. She received her Bachelor of Science in 1990 and Masters of Business Administration in 1991 from Indiana University of Pennsylvania. She was awarded a Doctor of Philosophy in 2001 from Southern Illinois University at Carbondale with a major in Management Information Systems and a minor in Production/Operations management. Her teaching specialties are in serverside programming and web application design and development. Her research interests include IT education, e-commerce, industrial economics, business ethics, banking, and finance studies. 